\title{
DYSKINESIA INDUCED BY PHENYTOIN
}

\author{
M. AUGUSTA MONTENEGRO*, ANNA ELISA SCOTON/**, FERNANDO CENDES ***
}

\begin{abstract}
Phenytoin is an effective antiepileptic drug, although, it can be associated with many side effects, including dyskinesia. Objective: To describe the clinical characteristics of phenytoin induced dyskinesia. Methods: We investigated the occurrence of involuntary movements in patients followed at our adult and pediatric epilepsy clinics during the period of one year. Results: Three patients presented with phenytoin-induced dyskinesia: one adult with axial and orofacial dyskinesia, and two children with choreoathetosis. They did not have other signs of phenytoin intoxication and had complete recovery after phenytoin withdrawal. Conclusion: Phenytoin induced dyskinesia may occur during either chronic or initial treatment and with normal serum phenytoin levels. However, it occurs most often in patients on polytherapy, usually after increasing dosage and with toxic serum levels. Other signs of phenytoin intoxication may be present in these patients, but often the dyskinesia is the only side effect, which may delay the diagnosis and treatment. The clinical characteristics of the involuntary movements vary and may be focal or generalized, most often characterized by choreoathetosis and dyskinesias. These may last for hours, days or even years, but frequently disappear completely after phenytoin withdrawal.
\end{abstract}

KEY WORDS: phenytoin, dyskinesia, involuntary movement

\section{Discinesia induzida por fenitoína.}

RESUMO - Fenitoína é droga anti-epiléptica eficaz, mas pode estar associada a vários efeitos colaterais, inclusive discinesia. Objetivo: Descrever as características clínicas da discinesia induzida por fenitoína. Método: Avaliamos a ocorrência de movimentos involuntários em pacientes seguidos nos ambulatórios de epilepsia durante o período de um ano. Resultados: Três pacientes apresentaram discinesia induzida por fenitoína: um adulto com discinesia orofacial e duas crianças com coreoatetose. Eles não tinham outros sinais de intoxicação por fenitoína e apresentaram recuperação completa após a retirada da fenitoína. Conclusão: Discinesia induzida pela fenitoína pode ocorrer durante tratamento crônico ou no início do tratamento e com níveis séricos normais de fenitoína. Entretanto, na maioria das vezes ocorre em politerapia e geralmente após aumento da dose e com níveis tóxicos de fenitoína. Outros sinais de intoxicação podem estar presentes, mas muitas vezes a discinesia é o único efeito adverso, o que pode atrasar o diagnóstico e tratamento. Os movimentos involuntários podem ser focais ou generalizados. Podem durar horas, dias ou até anos, mas freqüentemente desaparecem completamente após a retirada da fenitoína.

PALAVRA-CHAVE: fenitoína, discinesia, movimento involuntário.

Phenytoin is a widely used anticonvulsant, considered to be one of the first line drugs for partial seizures as well as for most forms of generalized seizures ${ }^{1}$. Despite its complex and unpredictable pharmacokinetic properties, phenytoin is usually safe, efficient, inexpensive and relatively easy to use. However, the use of this major anticonvulsant is limited by a number of side effects, which are mostly related to chronic use and high doses, including gingival hyperplasia, hirsutism, ataxia, nistagmus, tremor and somnolence ${ }^{1-4}$. A few reports have described phenytoin-induced focal dyskinesias that may

Departamento de Neurologia, Faculdade de Ciências Médicas (FCM) da Universidade Estadual de Campinas (UNICAMP): * Médica Residente, ** Médica do Hospital das Clínicas, *** Professor Assistente Doutor. Aceite: 02-fevereiro-1999.

Dr. Fernando Cendes - Departamento de Neurologia, FCM - UNICAMP - Caixa Postal 6111 - 13081-970 Campinas SP - Brasil. 
involve face, neck and limbs and are indistinguishable from those caused by neuroleptics ${ }^{2-39}$. Although rare, this side effect associated with the use of phenytoin is an important differential diagnosis among involuntary movement disorders, and need to be characterized further.

The purpose of this study was to determine the clinical characteristics of phenytoin induced involuntary movements in our patients and those described in the literature.

\section{METHOD}

This study was conducted at the adult and pediatric epilepsy clinics of our university hospital. During a period of one year the total number of patients seen on our service was 1,213 adults and 583 children. Patients with suspected or definite diagnosis of involuntary movement disorders were re-examined by one of the authors, and a detailed history, complementary exams, including drug levels, and follow up evaluations were obtained to confirm the association between the use of phenytoin and involuntary movements in these patients.

We also attempted to determine the type and dosage of anticonvulsant medication taken by patients followed in our clinics.

\section{RESULTS}

During the year of 1997 we observed three patients, one adult woman and two children, with involuntary movements induced by phenytoin. The clinical histories and semiology of these three patients are summarized below. We did not find dyskinesias in patients taking other anticonvulsant drugs during that same period. Among the adults, $51 \%$ of the patients were taking phenytoin, with the dosages varing from 50 to $525 \mathrm{mg} /$ day (mean $=320 \mathrm{mg} /$ day and median $=350 \mathrm{mg} /$ day), and among the children $22.5 \%$, with the dosages varing from 3 to $12 \mathrm{mg} / \mathrm{kg} /$ day (mean $=7.5 \mathrm{mg} / \mathrm{kg} /$ day and median $=7.7 \mathrm{mg} / \mathrm{kg} /$ day).

Patient 1. A 45 years old woman, with partial seizures of temporal lobe origin since age 3, never well controlled despite adequate anticonvulsant regimen. She was seen in a routine consultation and referred that since approximately one month prior to the consultation she started with abnormal movements. These were observed in the neurological examination as axial dyskinesia involving the neck with version of the head backwards and to the right, as well as orofacial dyskinesias including eyebrow elevation, blepharospasm, and occasional tongue protrusion and facial grimacing. In addition, there were large amplitude proximal movements of the right arm, and less frequent distal choreic movements. This patient had never presented with any kind of involuntary movements. She had been taking phenytoin on monotherapy for 10 months, with progressive increasing of dosage up to $400 \mathrm{mg} /$ day, initially with moderate reduction of her seizure frequency. There was no prior history of treatment with neuroleptic medications and no family history of involuntary movement disorders. The neurologic examination did not reveal abnormalities other than those described above. Cranial magnetic resonance imaging (MRI) showed atrophy and signal changes of the right medial temporal lobe structures. CT scan showed punctual calcifications over the right frontal and parietal lobes. Serial EEGs showed interictal epileptiform abnormalities over the temporal lobe regions with clear right-sided predominance. Blood tests, including electrolytes, renal and hepatic function and ceruloplasmin levels were normal. Serum level of phenytoin was $21.0 \mu 1$ ("therapeutic window": $10-20 \mu 1$ ). The dosage of phenytoin was tapered down and replaced by valproic acid, with progressive reduction and cessation of the involuntary movements after 3 months. After that, she had an increase in seizure frequency and was taken to an emergence room of another hospital where phenytoin was re-introduced with a dosage of $200 \mathrm{mg} /$ day. Two days later, the same involuntary movements re-appeared, and again disappeared after phenytoin withdraw. This patient has been followed for 1 year after the second episode of dyskinesia, without recurrence of the abnormal movements.

Patient 2. A 3 years old girl with partial seizures since the age of 3 months, followed in our pediatric epilepsy clinic, was seen in the emergence room because of choreoathetotic movements involving face and upper extremities since approximately 8 hours. She was taking $23,0 \mathrm{mg} / \mathrm{kg} / \mathrm{day}$ 
of valproic acid and $6,1 \mathrm{mg} / \mathrm{kg} /$ day of phenytoin. Phenytoin had been introduced 15 days before as an attempt to replace valproic acid. She was born prematurely with low birth weigh $(1900 \mathrm{~g})$ and had an episode of Todd's paralysis after a seizure in the first year of life. There were no other pathological antecedents. The neurologic examination did not show abnormalities other than those described above. Cranial CT and cerebrospinal fluid (CSF) were normal. Serologic testing for syphilis, cytomegalovirus, toxoplasmosis and smallpox were negative. Phenytoin level was $20.2 \mu \mathrm{g} / \mathrm{ml}$. Phenytoin was withdrawn and valproic acid increased to the previous dosage. The choreoathetoic movements disappeared completely after 12 hours. This patient has been followed for 10 months and had no further abnormal involuntary movements.

Patient 3 . A 9 years old boy with medically resistant partial seizures since the age of 9 months, and delayed mental and motor milestones. He was seen in a routine follow up visit when his mother referred that he started with abnormal movements approximately 30 days before ( 15 days after the introduction of phenytoin). The neurologic examination showed choreoathetotic movements involving face, tongue and upper extremities. At that moment he was taking $52 \mathrm{mg} / \mathrm{kg} /$ day of valproic acid, $0.3 \mathrm{mg} / \mathrm{kg} /$ day of nitrazepam and $6.6 \mathrm{mg} / \mathrm{kg} /$ day of phenytoin. He had used several combinations of anticonvulsant medications since the beginning of treatment, including the association of valproic acid and phenytoin in higher doses 3.5 years before, without seizure control and no history of involuntary movements. There were no other pathological antecedents or family history for involuntary movement disorders. Cranial MRI and CT, battery for inborn errors of metabolism, blood chemistry and hepatic enzymes were all normal. Serum level of phenytoin at that time was not available. Phenytoin was discontinued and dosages of valproic acid and nitrazepam were adjusted. The choreoathetotic movements disappeared completely after two days. He has been followed for 11 months with no indication of further abnormal movements.

\section{DISCUSSION}

Involuntary movements have been reported in patients using antiepileptic drugs, including carbamazepine, phenobarbital and phenytoin ${ }^{2,40,41}$. Although rare, phenytoin-induced dyskinesia has been well documented ${ }^{2-39}$.

We present here three patients, one adult and two children, with phenytoin-induced dyskinesia ascertained during the year of 1997 among our patient population of 1,213 adults and 583 children.

One of our patients (Patient 3) had already used phenytoin and valproic acid before the dyskinectic event. At that time he developed axial and apendicular ataxia without any evidence of dyskinesia. Phenytoin was discontinued with complete recovery. Three years and 6 months later the association of phenytoin and acid valproic was tried again and despite lower doses he presented choroathetosis involving face, tongue and upper extremities.

We found reports of 79 patients with dyskinesias induced by phenytoin. Sufficient clinical information about the symptomatology was available for 60 of these patients ${ }^{3-39}$. One patient had dyskinesia prior to the phenytoin administration, which aggravated the abnormal movement ${ }^{11}$. We will not discuss here reports about tremor, asterixis and myoclonus since these are less specific abnormalities seen in a wide range of metabolic and toxic disorders. Thirty two patients $(53.4 \%)$ were male and $27(45 \%)$ were female (one was not specified). Nineteen $(31.7 \%)$ were younger than 14 years old, 27 (45\%) had ages between 15 and 40 years old and $14(23.3 \%)$ were older than 40 years old. The distribution of the types of dyskinesia is shown on Table 1.

Sometimes when the patient was on polytherapy it was difficult to establish which drug was responsible for the abnormal movements. In most cases the clinical picture showed a clear relationship between phenytoin and the adverse reaction (toxic levels of phenytoin, appearance after phenytoin administration or disappearance following reduction and withdrawal of this drug). In a few cases we 
Table 1. Distribution of the types of phenytoininduced dyskinesia reported in the literature ${ }^{3-39}$.

\begin{tabular}{lc}
\hline Dyskinesia & Number of patients* (\%) \\
\hline Choreoathetosis & $46(76.6)$ \\
Dystonia & $17(28.3)$ \\
Orofacial dyskinesia & $13(21.6)$ \\
Ballism & $05(08.3)$ \\
\hline
\end{tabular}

*Some patients had more than one type of dyskinesia.
Table 2. Relation between phenytoin-induced dyskinesia, number of drugs taken and phenytoin level in 46 patients reported in the literature ${ }^{15,21,37,39}$.

\begin{tabular}{lll}
\hline Phenytoin level & Monotherapy & Polytherapy \\
\hline Toxic & $6(12.8 \%)$ & $23(48.9 \%)$ \\
Non-toxic & $7(14.9 \%)$ & $11(23.4 \%)$ \\
\hline
\end{tabular}

could not be sure about the relationship between phenytoin and the involuntary movements; however, we believe these were induced by phenytoin, at least in part.

Dyskinesia may be seen during chronic or initial treatment, more often among patients on polytherapy, during increasing dosages and toxic serum levels of phenytoin, and in patients with brain lesions ${ }^{15,21,37,39}$ (Table 2).

Involuntary movements induced by phenytoin vary in nature and may be focal or generalized 8,15. Choreoathetosis and dystonia are the most common (Table 1). Other signs of phenytoin intoxication may be present ${ }^{13,16,28}$, however, dyskinesia can be the only side effect, which may delay the diagnosis and treatment ${ }^{37}$. In $63.3 \%$ of the patients reported, there were other signs of phenytoin intoxication, but in $30 \%$ only dyskinesia was present.

Phenytoin-induced dyskinesias may last hours, days or even years and usually disappear after phenytoin withdrawal ${ }^{3,13,37}$. Diazepam may be used to alleviate the symptoms ${ }^{3}$.

Shulman et al. ${ }^{37}$ reported a patient with choreoatetoic movements during 8 years that began 22 years after introduction of phenytoin. These abnormal movements disappeared completely 6 months after phenytoin withdrawal.

Phenytoin-induced dyskinesias are most often seen in children and young adults. Harrison et al. ${ }^{15}$ reported that $50 \%$ of the patients described in the literature were younger than 20 years of age, and only $20 \%$ were older than 40 years of age. This is in agreement with our finding that phenytoininduced dyskinesia was 5 to 6 times more frequent in children compared to adults followed in our epilepsy clinic.

The pathophysiology of the phenytoin-induced dyskinesia has not been completely established. After administration of $25 \mathrm{mg} / \mathrm{kg} /$ day of phenytoin to rats during 20 days, Lalonde ${ }^{22}$ concluded that the dopaminergic hypersensitivity after long term treatment might be partially responsible for the phenytoin-induced dyskinesia in epileptic patients. Harrison et al. ${ }^{15}$ hypothesized that there is a disturbance in the functional equilibrium of the basal ganglia output systems, perhaps due to a differential effect of phenytoin on dopamine receptor subtypes or their associated second messenger systems.

Despite several previous reports of phenytoin-induced dyskinesia, this diagnosis may be often overlooked. The phenytoin serum level may not be toxic and the patient may not have other clinical signs of intoxication ${ }^{7,15,30}$. It is important to emphasize that the hypothesis of adverse reaction to phenytoin must be considered as a differential diagnosis in every patient presenting with involuntary movements during phenytoin therapy. This is a situation with excellent prognosis after drug withdrawal.

Acknowledgements - We thank all the staff and residents from the Neurology Department at UNICAMP for their invaluable help on this project. 


\section{REFERÊNCIAS}

1. Wilder BJ. Phenytoin: clinical use. In Levy RH, Mattson RH, Meldrum BS (eds). Antiepileptic drugs. 4.Ed. New York: Raven Press, 1995;339-344.

2. Bruni J. Toxicity. In Levy RH, Mattson RH, Meldrum BS (eds). Antiepileptic drugs. 4.Ed. New York: Raven Press, 1995;345350.

3. Ahmad S, Laidlaw J, Houghton GW, Richens A. Involuntary movements caused by phenytoin intoxication in epileptic patients. J Neurol Neurosurg Psychiatry 1975;38:225-231

4. Bellman MH , Haas L. Toxic reaction to phenytoin. Br Med J 1974;2: 256-257

5. Buchanan N, Rosen E, Rabinowitz L. Athetosis and phenytoin toxicity. Am J Dis Child 1977; 131: 105-106.

6. Chadwik D, Reynolds EH, Marsden CD. Anticonvulsivants-induced dyskinesias: a comparison with dyskinesias induced by neuroleptics. J Neurol Neurosurg Psychiatry 1976;39:1210-1218.

7. Chalhub EG, DeVivo DC, Volpe JJ. Phenytoin-induced dystonia and choreoathetosis in two retarded epileptic children. Neurology 1976;26:494-498.

8. Choonara IA, Rosenbloom L. Focal dystonic reaction to phenytoin. Dev Med Child Neurol 1984;26:677-680.

9. Corey A, Koller W. Phenytoin induced dystonia. Ann Neurol 1983;14:92-93

10. Crosley CJ, Swender PT. Dystonia associated with carbamazepine administration: experience in brain damage children. Pediatrics 1979; 63: 612-615.

11. DeVeaugh-Geiss J. Aggravation of tardive dyskinesia by phenytoin. N Engl J Med 1978;298:457-458.

12. Diehl L. Nil nocere! Ungewohnliche hyperkinetische Syndrome nach Diphenylhydantoin- Medikation. Munchen Med Wochenschr 1969;3:1679-1681

13. Filloux F, Thompson J A. Transient chorea induced by phenytoin. Pediatr 1987;110:639-641.

14. Gerber N, Lynn R, Oates J. Acute intoxication with 5,5-diphenylhydantoin (dilantin) associated with impairment of biotransformation. Ann Intern Med 1972;77:765-771.

15. Harrison M B, Lyons G R, Landow E R. Phenytoin and dyskinesias: a report of two cases and review of the literature. Mov Disord 1993;8:19-27.

16. Hoaken PCS, Francis JK Jr. Unusual brain syndrome seen with diphenylhydantoin and pentobarbital. Am J Psychiatry 1963;120:282-283.

17. Howrie DL, Crumrine PK. Phenytoin-Induced movement disorder associated with intravenous administration for status epilepticus. Clin Pediatr 1985;24:467-469.

18. Kirschberg GJ. Dyskinesia: a usual reaction to ethosuximide Arch Neurol 1975;32:137-138.

19. Kooiker JC, Sumi SM. Movement disorder as a manifestation of diphenylhydantoin intoxication. Neurology 1974;24:68-71.

20. Krishnamoorthy KS, Zalneraitis EL, Young RSK, Bernard PG. Phenytoin-induced choroathetosis in infancy: case report and a review. Pediatrics 1983,72:831-834.

21. Kurata K, Kido H, Kobayashi K, Yamaguchi N. Long-lasting movement disorder induced by intravenous phenytoin administration for status epilepticus: a case report. Clin Neuropharmacol 1988;11:467-471.

22. Lalonde R. Dopaminergic supersensitivity after long-term administration of phenytoin in rats: Epilepsia 1985;26:81-84.

23. Lazaro R P. Involuntary movements induced by anticonvulsivant drugs, Mt Sinai J Med 1982;49:274-281.

24. Logan WJ, Freeman JM. Pseudodegenerative disease due to diphenylhydantoin intoxication. Arch Neurol 1969;21:631-637.

25. Lundorf K, Lund M. Phenytoin-induced hyperkinesia. Epilepsia 1977;18:409-415.

26. Mauguirere F, Dalery J, deVillard R et al. Transient hyperkinesia after a single intravenous perfusion of diphenylhydantoin. Eur Neurol 1979;18:116-123.

27. McLellan DL, Swash M. Choreoathetosis and encephlopathy induced by phenytoin. Br Med J 1974;2:204-205.

28. Micheli F, Lehkuniec E, Gatto M, Pelli M, Asconape J. Hemiballism in a patient with partial motor status epilepticus treated with phenytoin. Func Neurol 1993;8:103-107.

29. Moss W, Ojukwu C, Chiriboga CA. Phenytoin-induced movement disorder: unilateral presentation in a child and response to diphenhydramine, Clin Pediatr 1994;33:634-636.

30. Nausieda PA, Koller WC, Wiener WJ, et al. Clinical and experimental studies of phenytoin-induced hyperkinesia. J Neural Transm 1979;45:291-305.

31. Opida CL , Korthals JK, Somasundaram M. Bilateral balismus in phenytoin intoxication. Ann Neurol 1978;3:186.

32. Peters HA, Eichman PL, Price JM et al. Abnormal copper and tryptophan metabolism and chelation therapy in anticonvulsant drug intolerance. Dis Nerv Syst 1966;28:97-107.

33. Rasmusen S, Kristensen M. Choreoathetosis during phenytoin treatment. Acta Med Scand 1977;201:239-241.

34. Reimer F, Christini K. Motorische Reizerscheinungen nach Diphenyl-hydantointoxikation. Nervenartz 1967;38:509-615.

35. Reynolds EH, Trimble MR. Adverse neuropsychiatric effects of anticonvulsivant drugs. Drugs 1985;29:570-581.

36. Rosenblum E, Rodichok L, Hanson PA, et al. Movement disorder as a manifestation of diphenylhydantoin toxicity. Pediatrics 1974;54:364-366.

37. Shulman L M, Singer C, Weiner W J. Phenytoin-induced focal crorea. Mov Disord 1996;11:111-114.

38. Shuttleworth E, Wise G, Paulson G. Choreoathetosis and diphenylhydantoin intoxication. JAMA 1974;230:1170-1171.

39. Tomson T. Choreoathetosis induced by ordinary phenytoin levels, explained by high free fraction? A case report. Ther Drug Monit 1988;10:139-241.

40. Joyce RP, Gunderson CH. Carbamazepine-induced orofacial dyskinesia. Neurology 1980;30:1333-1334.

41. Wiznitzer M, Yiunkin D. Phenobarbital-induced dyskinesia in a neurology-impaired child. Neurology 1984;34:1600-1601.

42. Hulley SB, Cummings SR. Designing in clinical research. Baltimore, Williams \& Wilkins 1988. 